http://jmscr.igmpublication.org/home/ ISSN (e)-2347-176x ISSN (p) 2455-0450 crossref DOI: https://dx.doi.org/10.18535/jmscr/v7i8.62

\title{
Comparative Study of Effects of Epidural Tramadol and Epidural Buprenorphine on Post Operative An-Algesia in Young Adults
}

\author{
Authors \\ Dr Ranbhushan Singh ${ }^{1}$, Dr Indra Bhatyal ${ }^{2}$, Dr Konika Razdan ${ }^{3}$, Dr Satya Dev Gupta ${ }^{4^{*}}$ \\ ${ }^{1}$ Anaesthesia Specialist, ${ }^{2}$ PG Deptt of Gynae Obstetrics, GMC Jammu \\ ${ }^{3}$ Research Scientist I, VRDL, Dept of Microbiology, GMC Jammu \\ ${ }^{4}$ Associate Professor, Department of Anaesthesia, Govt. Medical College, Jammu \\ *Corresponding Author \\ Dr Satya Dev Gupta \\ Associate Professor, Department of Anaesthesia, Govt. Medical College, Jammu, India
}

\begin{abstract}
The alleviation of pain, both acute and chronic is an important concern in medical profession. The worldwide search for an appropriate drug to relieve post operative pain is still continuing. Present study was undertaken in search of a better analgesic for post operative analgesia. The study compared $50 \mathrm{mg}$ tramadol given epidurally with $0.15 \mathrm{mg}$ epidural buprenorphine. No other analgesics or sedatives were used. All cases were conducted under regional anaesthesia and the drug was administered through epidural catheter in L 2-3 epidural space. Peak effect of tramadol was for 4 hours whereas with buprenorphine it was 8 hours. The study concluded that he analgesic potency of tramadol is good but much less than that of buprenorphine.

Keywords: Epidural tramadol; Epidural buprenorphine, Post operative analgesia.
\end{abstract}

\section{Introduction}

The relief of post operative pain in general surgery represents one of the clinical areas in which precise standardization does not exist despite the enormous mass of data published in the literature of this subject (Gupta et al., 2010). The psychological, physiological and socioeconomic effects of unrelieved pain are considerable, prominent among them being with patient anxiety, restlessness, tachycardia, rise in blood pressure, pulmonary infection and hypoxaemia along with an increased duration of hospital stay and nursing care (Vadivelu et al., 2010). For the treatment of post operative pain, two categories of drugs are available i.e. Narcotic and non-narcotic analgesics. Among the narcotic analgesics, tramadol is an opioid agonist of synthetic origin while buprenorphine is a derivative of the baine, an opium alkaloid related to morphine and is long acting analgesic with partial agonist action (Pharmacological Management of Cancer Pain in Adults).

The present study was conducted to assess the analgesic activity of tramadol as compared to buprenorphine given through epidural route.

\section{Materials and Method}

Pre-anaesthetic medication was done with oral diazepam $10 \mathrm{mg}$, night before surgery. Injection atropine $0.6 \mathrm{mg}$ intramuscular was given $45 \mathrm{~min}$ before surgery. For epidural anaesthesia, Tuohy needle was inserted with patient in lateral position 
at L 2-3 or L 3-4 levels. Epidural catheter was passed through needle. An initial dose of $5 \mathrm{ml}, 2 \%$ lignocaine with adrenaline 1 in 2,00,000 was injected through this, followed by an additional 15 $\mathrm{ml}$ of lignocaine. All the cases were studied in hysterectomy surgery. The epidural catheter was left in situ for administration of opioids for post operative analgesia. No drug other than the drug under study was administered during surgery for analgesia. In 25 patients, tramadol $50 \mathrm{mg}$ was given epidurally diluted in $10 \mathrm{ml}$ of normal saline. While in other 25 patients, buprenorphine $0.15 \mathrm{mg}$ was given epidurally, diluted in $10 \mathrm{ml}$ of normal saline.

Assessment was done before giving the drug and up to 24 hours post operatively. A total of four doses of drug were given in 24 hours. Pain intensity was scored as $0=$ no pain, $1=$ mild, $2=$ moderate and $3=$ severe. Pain relief was scored as $0=$ no relief, $1=$ slight, $2=$ moderate and $3=$ complete. Any adverse events were recorded along with pulse rate, blood pressure, respiratory rate, nausea, vomiting and dizziness etc.

\section{Observations \& Results}

In both the groups, patients were between the age groups of 21 and 57 years, weights were between $35 \mathrm{~kg}$ and $49 \mathrm{~kg}$. Mean duration of surgery was 103 minutes. In the two groups there was no significant difference between changes in pulse rate, respiratory rate and blood pressure.

Thus as shown in Table I, II \& III incidence of side effects was same but buprenorphine is better epidural analgesic $(0.15 \mathrm{mg})$ than tramadol (50 $\mathrm{mg}$ ) in lower abdominal surgery.

Table I Pain intensity before given the drug

\begin{tabular}{|l|c|c|}
\hline & $\begin{array}{c}\text { Tramadol Group } \\
\mathrm{n}=25\end{array}$ & $\begin{array}{c}\text { Buprenorphine } \\
\text { Group } \mathrm{n}=25\end{array}$ \\
\hline Mean & 2.6 & 2.56 \\
\hline $\mathrm{SD}$ & 0.50 & 0.506 \\
\hline ' $\mathrm{t}$ ' $=0.281$ & $\mathrm{p}>0.05 \quad-$ & Not significant \\
\hline
\end{tabular}

Pain intensity was similar for the two groups before given the drug.

Table II Total pain relief

\begin{tabular}{|l|c|c|}
\hline & $\begin{array}{c}\text { Tramadol Group } \\
\mathrm{n}=25\end{array}$ & $\begin{array}{c}\text { Buprenorphine } \\
\text { Group } \mathrm{n}=25\end{array}$ \\
\hline Mean & 11.86 & 18.32 \\
\hline SD & 2.62 & 4.12 \\
\hline 't' $=0.281$ & $\mathrm{p}>0.05-$ & Significant \\
\hline
\end{tabular}

Statistically, total pain relief differs significantly between the two groups $(\mathrm{p}<0.001)$. It is higher in buprenorphine group.

Table III Side effects seen in both groups (\%)

\begin{tabular}{|l|c|c|}
\hline & Tramadol & Buprenorphine \\
\hline Dizziness & 8 & - \\
\hline & 4 & 70 \\
\hline Nausea & 4 & 8 \\
\hline Vomiting & - & 4 \\
\hline Dry mouth & 20 & - \\
\hline Respiratory depression & 4 & - \\
\hline Injection discomfort & - & 4 \\
\hline
\end{tabular}




\section{Discussion}

Narcotic analgesics are still indispensable for the treatment of severe pain (Brennan et al., 2016: Lohman et al., 2010) and a major objective in analgesics research has been to obtain an agent with desirable analgesic properties of morphine, but free from its side effects such as addiction and respiratory depression. Buprenorphine is a synthetic analgesic exhibiting a partial agonistic activity at the mu-opioid receptors. Tramadol acts via opioid receptors, showing some selectivity for the mu-receptors (Pathan and Williams, 2012). Non opioid mechanism of action also contributes to the anti-nociceptive profile of tramadol (Gholami et al., 2015). In non opioid mechanism of tramadol, it inhibits noradrenaline uptake and stimulates sertonin release, and these are transmitters in descending pathways which enhance analgesia without respiratory depression. Mean summed pain intensity difference (SPID) in our study for buprenorphine is 13.50 where as for tramadol is 9.40 . This value is slightly higher than that of Dobkin (1977). This might be because he had used five point scale for pain intensity measurement whereas we have used a four point scale. In a study, by Baraka et al., 1993 SPID for $50 \mathrm{mg}$ tramadol given epidurally was 8.86 and for morphine $4 \mathrm{mg}$ to be 7.32 in patients of postoperative lower abdominal surgery.

Total pain relief (PR tot) in our study for buprenorphine was 18.32 hours and for tramadol was 11.86 hours. Dobkin (1977) in a study on buprenorphine $1.15 \mathrm{mg}$ demonstrated PR tot equal to 16.6 hours. This was due to difference in the scale used for measurement of pain intensity. Onset of action was almost similar with both the drugs. Significant pain relief was seen within 3045 minutes of administration of drugs which is similar to the study by Gadani et al., (2017). Koshy (2005) demonstrated that duration of analgesia with $0.15 \mathrm{mg}$ buprenorphine epidurally was 19 hours 55 minutes and the SD was 8 hours which is also almost similar to our study. Dobkin (1977) observed that the commonest side effect was drowsiness in $40 \%$ patients receiving $0.3 \mathrm{mg}$ buprenorphine, while in our study $70 \%$ of patients were drowsy after one hour of injection. In tramadol group $8 \%$ patients reported dizziness, sedation in 4\% while Gadani et al., (2017) have reported dizziness in $6.54 \%$ of patients and sedation in $2.52 \%$ of patients.

\section{Conflict of interest: None Declared}

Acknowledgements: Authors are thankful to the patients for their support and co-operation.

\section{References}

1. Gupta A, Kaur K, Sharma S, Goyal S, Arora S, and Murthy RSR. Clinical aspects of acute post-operative pain management \& its assessment. J Adv Pharm Technol Res. 2010 Apr-Jun; 1(2): 97-108.

2. Vadivelu N, Mitra S, and Narayan D. Recent Advances in Postoperative Pain Management. Yale J Biol Med. 2010 Mar; 83(1): 11-25

3. Pharmacological Management of Cancer Pain in Adults National Clinical Guideline No. 9. www.health.gov.ie/patientsafety/ncec

4. Brennan F, Carr D and Cousins M. Access to Pain Management-Still Very Much a Human Right. Pain Medicine 2016; 17: 1785-1789

5. Lohman D, Schleifer R, Amon JJ. Access to pain treatment as a human right. BMC Medicine 2010, 8:8

6. Pathan $\mathrm{H}$ and Williams J. Basic opioid pharmacology: an update. British Journal of Pain 6(1) 11-16

7. Gholami M, Saboory E, Mehraban S, Niakani A, Banihabib N, Azad MR and Fereidoni J. Time Dependent Antinociceptive Effects of Morphine and Tramadol in the Hot Plate Test: Using Different Methods of Drug Administration in Female Rats. Iran J Pharm Res. 2015 Winter; 14(1): 303-311 
8. Dobkin AB. 1977. Buprenorphine hydrochloride: determination of analgesic potency. Can Anaesth Soc J 24:186-193

9. Baraka A, Jabbour S, Ghabash M, Nader A, Khoury G. A comparison of epidural tramadol and epidural morphine for post operative analgesia. Can J Anaesthesia 1993, April 40(4): 308-13.

10. Gadani HN, Patel NB and Gupta SC. Role of butorphanol in preemptive analgesia: A comparison with pentazocine. Anaesth, Pain \& Intensive Care 2017;21(1):44-51

11. Koshy RC, Kuriakose R, Sebastian P et al. Continuous morphine infusions for cancer pain in resource-scarce environments: comparison of the subcutaneous and intravenous routes of administration. J Pain Pall Care Pharmacother 2005;19:2733. 